\title{
A Common Currency for Belarus and Russia?
}

\author{
Anne-Marie Gulde, Etibar Jafarov, and \\ Vassili Prokopenko
}




\title{
IMF Working Paper
}

European and Monetary and Financial Systems Departments

\section{A Common Currency for Belarus and Russia?}

\author{
Prepared by Anne-Marie Gulde, Etibar Jafarov, and Vassili Prokopenko ${ }^{1}$
}

December 2004

\begin{abstract}
This Working Paper should not be reported as representing the views of the IMF. The views expressed in this Working Paper are those of the author(s) and do not necessarily represent those of the IMF or IMF policy. Working Papers describe research in progress by the author(s) and are published to elicit comments and to further debate.

This paper discusses costs, benefits, and implementation challenges of a possible currency union between Belarus and Russia. It shows that Belarus and Russia are economically closely linked but nevertheless do not fulfill all "optimal currency area" criteria, especially the macroeconomic symmetry condition. Furthermore, we argue that the different speeds of economic liberalization over the past decade have resulted in different economic structures, with Belarus still dependent on monetary financing of budgets and industries. However, a final cost-benefit analysis also needs to consider that currency unification may bring substantial benefits from reduced transaction costs, an improved macroeconomic environment in Belarus, and by acting as a catalyst to advance structural reforms in Belarus.
\end{abstract}

JEL Classification Numbers: E42; F31; F33

Keywords: currency union; monetary union; Belarus; Russia

Author(s) E-Mail Address: aguldewolf@imf.org; ejafarov@imf.org; and vprokopenko@imf.org

\footnotetext{
${ }^{1}$ At the time of the preparation of this paper, Anne-Marie Gulde was a Division Chief in the Monetary and Financial Systems Department, and she is now an Advisor in the African Department. Vassili Prokopenko is an Economist in the Monetary and Financial Systems Department, and Etibar Jafarov is an Economist in the European Department. The authors would like to thank Veronica Bacalu, Balazs Horvath, Mark O’Brien, Thomas Richardson, Andrea Schaechter, Mark Swinburne, Jerome Vacher, and participants of the EUR and UACES seminars for helpful comments on earlier drafts.
} 


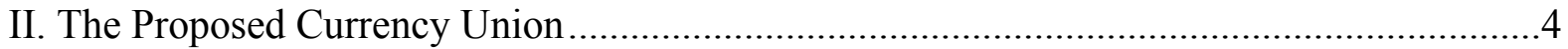

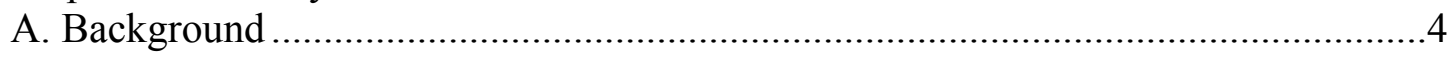

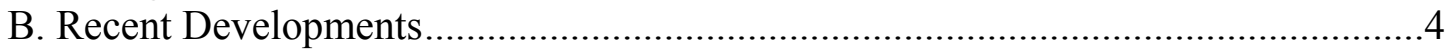

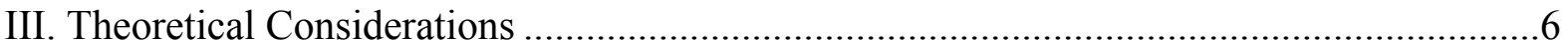

A. Economic Costs and Benefits of a Currency Unification ..................................6

B. Preconditions on the Operating Environment .................................................. 10

C. Setting Up an Asymmetric Currency Union .....................................................13

IV. Economic Costs and Benefits of Currency Unification Between Belarus and Russia ......16

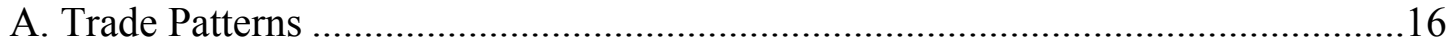

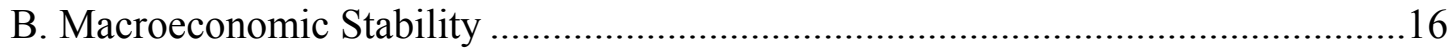

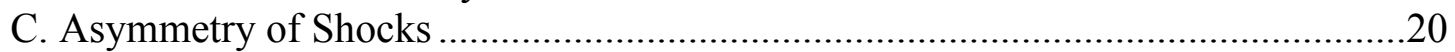

D. Are There Mechanisms to Deal with the Asymmetries? ......................................22

V. Is Operational Environment Supportive of a Currency Unification of Belarus and Russia?.24

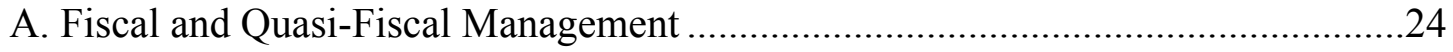

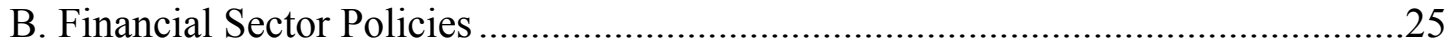

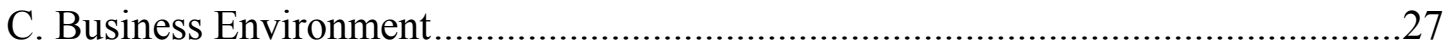

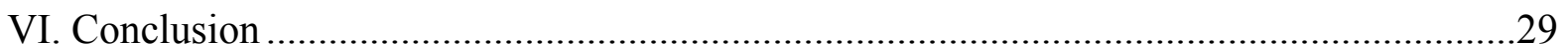

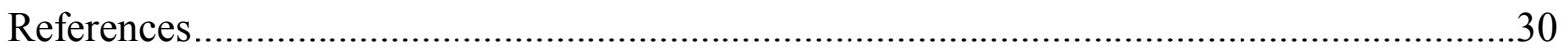

Tables

1. Belarus and Russia Monetary Integration: Chronology of Developments, 1992-2002 ........5

2. Belarus and Russia: Basic Data, 2000-03 ................................................................... 17

3. Belarus and Russia: Selected Financial Intermediation Indicators, 2000-03 ....................26

4. Belarus and Russia: Selected Financial Soundness Indicators, 2000-03 ........................28

Figures

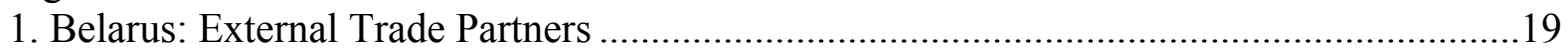

2. Russia: External Trade Partners ..................................................................................... 19

3. Belarus: GDP and Employment by Sectors ......................................................... 21

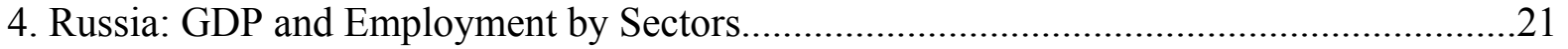

Boxes

1. Belarusian and Russian Views on the Nature of Currency Union....................................

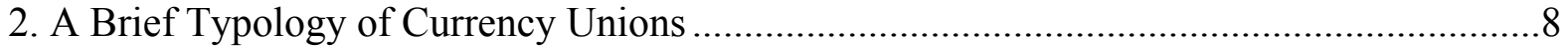

3. Distribution of Seignorage in a Currency Union .......................................................... 11 


\section{INTRODUCTION}

In recent years, a large number of countries have demonstrated strong interest in common currency arrangements. ${ }^{2}$ The arrangements that have been contemplated ranged from the establishment of a completely new currency union by two or more independent countries to the incorporation of one or several individual countries into the existing union. In a number of cases, for example in the countries now forming the European Monetary Union (EMU) and some Central American countries accepting the U.S. dollar, monetary union was implemented.

This paper discusses a proposed currency union for Belarus and Russia, with a focus mainly on the effects such union would have for Belarus. In evaluating the pros and cons, the paper starts from the classical "optimal currency area" criteria, but in addition highlights the importance of the economic structures and the institutional environment in both countries. Furthermore, given the disproportionate size of the economies of Belarus and Russia, the paper also notes the specific challenges stemming from the establishment of an "asymmetric" currency union between countries of different size and economic weight. The paper concludes that the outcome of a cost-benefit calculation at this stage remains uncertain, but that the potential gains for Belarus would increase if the country were to create more favorable initial conditions through a faster liberalization of its economy.

The structure of the paper is as follows. Section II briefly overviews the proposed currency union plan. Section III presents some theoretical considerations on the establishment of a currency union, with a special focus on issues involved in the creation of an "asymmetrical" currency union. ${ }^{4}$ Section IV discusses the existing economic conditions for the currency unification for Belarus and Russia, while Section V focuses on the institutional environment of this union. Section VI concludes.

\footnotetext{
${ }^{2}$ Common currency arrangements in this paper refer to the use of single currency in different countries. Hard pegs, such as currency boards that share many of the same costs and benefits, are not included in the definition of common currency for the purposes of this paper.

${ }^{3}$ This wave of interest in common currency arrangements has probably been sparked by the successful launch of the European Monetary Union, as well as some more general globalization trends. With more or less strong political, popular, and economic backing, talks are currently underway on the design of a possible currency union for several Latin American countries, an extended currency union for the Caribbean countries, a second West African currency union, a currency union for the Gulf Cooperation Council countries, a currency union for several Asian countries, etc.

${ }^{4}$ In this paper, we define a currency union as "asymmetric" when the relative sizes of the economies of member countries are of disproportionate dimensions and the members with small economies have a very limited influence over the common monetary and exchange rate policies.
} 


\section{The Proposed Currency Union}

\section{A. Background}

Discussions over monetary union between Belarus and Russia began in September 1993, only two months after the formal break-up of the ruble zone (Table 1 summarizes the chronology of these discussions). ${ }^{5}$ The negotiations - which at least until the late 1990s were largely politically driven - subsequently stalled for several years, reflecting the different and sometimes diverging path of economic reforms in the two countries. Specifically, the Belarusian authorities have favored a much more gradualistic approach to reforms than the Russian authorities, as a result of which the government in Belarus has remained heavily involved in many sectors of the economy. The Russian financial crisis of August 1998 further disrupted the integration process. Nevertheless, the idea of monetary and economic unification between the two countries has remained popular in both Russia and Belarus. ${ }^{6}$ The improved macroeconomic conditions in both countries following the 1998 crisis have contributed to the intensification of the currency unification talks.

In December 1999, the authorities of Belarus and Russia signed the Union State Treaty. Under the terms of this Treaty, which was concluded without much public debate, Belarus and Russia agreed to proceed with a broad economic integration, including the establishment of a joint monetary system. In this connection, an agreement signed by Belarus and Russia in November 2000 stipulated introduction of a common currency for the Union State from January $1,2008 .^{7}$

\section{B. Recent Developments}

In June 2002, the authorities of Belarus and Russia signed a Joint Action Plan (JAP) for the introduction of a common monetary unit of the Union State, covering the period through 2005. The JAP established 40 tasks viewed by the authorities as appropriate and which should be completed in order to establish conditions for the introduction of a single currency. These tasks included a variety of measures aimed at the convergence of macroeconomic, fiscal, monetary, foreign exchange, financial, trade, and structural policies, as well as the harmonization of the relevant legislation. The JAP also specified the timing for the implementation of these tasks, and stipulated that the Russian ruble may take on the role of the common currency for the Union State starting January 1, 2005, provided that all tasks and measures under this plan are implemented in full during the years 2002-04.

\footnotetext{
${ }^{5}$ For the discussion of the dissolution of the ruble area, see Odling-Smee and Pastor (2001).

${ }^{6}$ See Colton (2002).

${ }^{7}$ This agreement was signed shortly after the long delayed unification of official and black market exchange rates in Belarus.
} 
Table 1. Belarus and Russia Monetary Integration: Chronology of Developments, 1992-2002
Date
Event

May 1992

September 1993

April 1996

April 1997

January 1999

November 1999

December 1999

November 2000

June 2002
Belarus introduces a national currency to replace rubles of the USSR.

The Belarusian rubel becomes the sole legal tender in Belarus.

In the same month, the authorities of Belarus and Russia sign an agreement on the unification of the monetary systems. This largely politically driven agreement has never been implemented.

Belarus and Russia sign an agreement on the establishment of a Political and Economic Community. This agreement provided mainly for trade and some security issues. But it also laid the basis for the establishment of institutions for the new union state and for the creation of the conditions for a monetary union by harmonizing rules and laws, and by coordinating and synchronizing economic reforms.

The Community is transformed into a formal Union. The substantive nature of the cooperation did not however change significantly.

The National Bank of Belarus (NBB) and the Central Bank of Russia (CBR) approve a schedule of actions in the area of monetary integration. It includes measures to unify monetary policy instruments, to coordinate steps in the exchange rate policy of national currencies, and to work out common principles for currency regulation, preparation for payment systems' unification, and creation of conditions for free circulation of securities.

The Interbank Currency Council is established. It consists of five representatives of both the NBB and the CBR headed by their Governors. It is an advisory body whose main objectives are to coordinate the work in the sphere of monetary systems' integration and to prepare for the introduction of a single currency.

Belarus and Russia sign the Union State Treaty. This treaty calls for a broad economic integration, including the establishment of a joint monetary system.

Belarus and Russia sign an agreement that stipulates introduction of a common currency of the Union State from January 1, 2008.

Belarus and Russia sign a Joint Action Plan for the introduction of a common monetary unit of the Union State, covering the period through 2005. The Plan stipulates that, provided that all tasks and measures under the Plan are implemented in full during the years 2002-04, the Russian ruble may take on the role of the common currency for the Union State as of January 1, 2005.

Sources: various IMF Economic Reviews; and the authorities of Belarus (information available at the web site of the Embassy of Belarus in Russia http://www.embassybel.ru/index.php?page=27). 
Despite substantial preparatory work on the introduction of a common currency, some important procedural and institutional issues still remain subject to debate. These include the responsibility for the conduct of the common monetary policy, the availability of the LOLR facility in Belarus, the distribution of the central bank profits, etc. Failure to agree on these issues is primarily caused by a difference of opinion between the Belarusian and Russian authorities on the planned design of the "single emission center," which will assume the responsibility for the conduct of common monetary policy (Box 1).

\section{Theoretical Considerations}

\section{A. Economic Costs and Benefits of a Currency Unification}

There is a vast and growing body of literature on the implications of different exchange rate regimes for macroeconomic performance. Special attention is given to the analysis of costs and benefits of hard pegs and currency unions (Box 2 discusses different types of currency unions). ${ }^{8}$ The analysis of common currencies generally starts from the original ideas of Robert Mundell on optimal currency areas (Mundell, 1961). The main advantages and disadvantages for any country willing to establish a currency union with another country (or a group of other countries) can be summarized as follows (Frankel, 1999):

\section{- The principal advantage of a currency unification is the reduction of transaction} costs associated with the need to change currency to do business. Transaction costs from currency conversion are financial costs (commission fees and other administrative costs that economic agents have to pay to foreign currency dealers for foreign currency conversion) and in-house costs (costs associated with tying up resources to deal with foreign exchange management). ${ }^{9}$ The more countries are integrated, the greater will be the savings from setting up a currency union. Lower transaction costs, in turn, are likely to further increase trade, improve resource allocation, and contribute to higher growth. ${ }^{10}$

\footnotetext{
${ }^{8}$ An example is the emergence of the so-called "bipolar view" whose proponents believe that with increasing capital mobility intermediate exchange rate regimes between currency boards and free floating are unsustainable in the long term (Fischer, 2001). There is some empirical evidence of movements to either free floats or hard pegs (Ghosh, Gulde, and Wolf, 2003).

${ }^{9}$ Emerson, and others (1992) estimated that for the members of the European Monetary Union, total savings from abolishing conversion within Europe, including savings from "reductions in inefficiencies inside firms," were at 0.4 percent of GDP. For small open and less developed European economies, they estimated such savings at 1 percent of GDP.

${ }^{10}$ Frankel and Rose (2000) estimated that a currency union more than triples trade among member countries without diverting trade away from other trading partners.
} 


\section{Box 1. Belarusian and Russian Views on the Nature of Currency Union}

The persistent failure in recent years of the Belarusian and Russian authorities to agree on some important procedural and institutional issues regarding the establishment of the currency union is primarily caused by a difference of opinion between the two countries on the planned design of the "single emission center," which will assume the responsibility for the conduct of common monetary policy.

The authorities of Russia favor a centralized approach, where the functions of the single emission centre would be performed exclusively by the Central Bank of Russia (CBR). Under this scenario, the National Bank of Belarus (NBB) would be able to operate with currencies and securities only with the permission of and in volumes determined by the $\mathrm{CBR}$, though one or two representatives from the NBB may become members of the Board of Directors of the CBR. This model to a degree would mirror arrangements within European Monetary Union (EMU) and the Eurosystem, where the decision-making of a single emission centre is performed by the European Central Bank (ECB) Governing Council and the implementation, i.e., the operation with foreign currencies, is carried out by the ECB and by national central banks on the basis of these decisions.

The authorities of Belarus have been opposing the idea of losing the right to control money supply. The Belarusian counterproposal is to set up the single emission center with two central banks whose monetary policy would be coordinated by the Interbank Currency Council (ICC). As shown in Table 1, the ICC is an advisory body whose main objective is to coordinate the convergence of monetary policies and to prepare for the introduction of a single currency. The NBB suggests that the ICC set monetary policy guidelines, which should then be approved by the Union State Council and become mandatory for both central banks. The ICC would set limits for central bank emissions of money (which would be proportional to the countries' GDP shares) and it would also coordinate the legal and regulatory activities of the two central banks. The CBR and NBB would each maintain a lender-of-last-resort (LOLR) facility for the banks on its territory. The NBB proposes that the ICC have six board members from each of the two central banks; in case of a split vote the chairman, who would be from the CBR, would have the decisive vote.

The Russian authorities have voiced concern about the effectiveness of the framework proposed by the NBB, and have also pointed out that this framework would not be consistent with the currently ensured CBR independence. 


\section{Box 2. A Brief Typology of Currency Unions}

There are different types of currency unions with distinct features, and different implications for the role of the central bank. The distinctions relate to the degree to which member countries can participate in monetary policy making, the degree to which seignorage is shared, and the availability of the lender of last resort facility. The main types of currency unions are as follows:

- "Dollarization:" A country adopts (either with the agreement of the issuing country or unilaterally) another country's currency as legal tender. In general there is no sharing of seignorage, no involvement of the adopting country in monetary policy decisions, and no lender of last resort support from the issuing country to the adopting country. In spite of these limitations countries have opted for (or contemplated) dollarization for stabilization purposes, to gain credibility, to lower borrowing costs, or to avoid the costs of operating a full fledged central bank. Examples of dollarized countries or territories include Ecuador, El Salvador, Panama (all using the U.S. dollar), Liechtenstein (using the Swiss Franc), Andorra, Kosovo, Monaco, Montenegro, San Marino (using the Euro), and Kiribati (using the Australian dollar).

- Creation of a new monetary area: Two or more countries decide to replace their old currencies by a common new currency, issued by a joint institution and managed jointly by all countries involved in the union. Monetary policy is based on aggregate developments and may not be optimal for individual members, especially those with macroeconomic cycles differing from the average. There are generally some agreements on sharing of seignorage and lender of last resort facility. Examples include the European Monetary Union (EMU), the two CFA areas in Africa, and the Eastern Caribbean Currency Union (ECCU).*

- Joining an existing monetary area: A country adopts another country's existing currency or joins an existing monetary union and obtains some representation in the monetary policy institutions, some seignorage, and, possibly, some or full lender of last resort protection. (Depending on the relative size of the entities involved, smaller members may, however, have little influence on the common policy.) An example would be the East German adoption of the Deutschmark in 1990. Another example is the currency union that existed between Belgium and Luxembourg from 1922 to 1999. This is also the case for the new member countries joining the EMU.

* The ECCU operates under currency board rules with the U.S. dollar, and the two CFA areas operate under fixed exchange rate regime with the euro. This limits the joint monetary management in these countries. 
- The principal disadvantage of a currency unification is the loss of the possibility of absorbing big shocks via a devaluation/revaluation or an adjustment in domestic monetary policy. If the shocks or transmission mechanisms in one country of the currency union differ from those in another country of the same union, these countries would be better off by using independent monetary or exchange rate policies. This would help stabilize output and avoid a painful adjustment through changes in wages, prices, and employment.

A currency union would, therefore, be desirable for countries with strong trade and financial integration and similar economic structures. Under such circumstances, shocks are likely to affect member countries similarly, making a single monetary policy desirable/effective. Where countries are dissimilar, a common monetary policy is unlikely to be optimal for all members. In this regard, Boone and Maurel (1999) showed that those prospective EMU members whose economic cycle is close to that of Germany (the largest European economy) would benefit from adopting the euro.

If countries are facing asymmetric shocks but are highly integrated, the loss of monetary and exchange rate policies as stabilization tools could theoretically be compensated by other mechanisms. These include flexibility in prices and wages, the mobility of labor and other factors of production, or fiscal transfers. ${ }^{11}$

It should be noted that most studies on optimal currency area properties are backward looking and do not reflect changes in policy preferences. But some authors argue that a currency union represents a structural break and optimal currency area criteria could be satisfied ex post even if it is not fully satisfied ex ante. They relate this in part to changes in monetary policy and in part to closer international trade with other members of the currency union $^{12}{ }^{13}$ (Frankel and Rose, 1996).

\footnotetext{
${ }^{11}$ Some economists argue that redistribution of income through the federal government is one of the key reasons why the currency union in the United States, which originally did not represent an optimal currency area, has survived without major problems (Sala-i-Martin and Sachs, 1991). Other reasons include labor and capital mobility.

${ }^{12}$ From a theoretical viewpoint, more international trade may result in either tighter or looser correlations of business cycles. For example, if countries become more specialized in the goods in which they have comparative advantage as noted by Krugman (1993), more trade will cause the business cycles of countries to diverge. Alternatively, if demand shocks and intra-industry trade dominate, then more trade will cause the business cycles to become more similar.

${ }^{13}$ The short experiences of some countries of the EMU support this argument. For example, Italy, Spain, Portugal, Greece, Ireland - countries identified as "in the periphery" (see Bayoumi and Eichengreen, 1992) seem to have not suffered from the entrance into a currency union with Belgium, France, Germany, and the Netherlands-so-called "EC core countries".
} 


\section{B. Preconditions on the Operating Environment}

A successful monetary union must be supported by an adequate operating environment. ${ }^{14}$ In ideal conditions, this environment should ensure that the common monetary policy is conducted by an independent and accountable central bank, which is not constrained by fiscal and quasi-fiscal activities or by the presence of weak financial institutions in member countries of the monetary union. ${ }^{15}$

\section{Freedom from fiscal dominance}

The long-term sustainability of a monetary union requires the implementation of credible fiscal policies by all member countries of the union. Theoretically, a member country which is persistently unable to effectively manage public finances (i.e., to cover public expenditures by revenues) must either exit that monetary union and unilaterally monetize the budget deficit or remain in the union by persuading other members to inflate. Therefore, the fear of pressure to bail out governments with poor public finances requires the existence of ceilings on debt and deficits (the Maastricht Treaty conditions provided for such ceilings in the context of EMU).

Another key element of the institutional framework governing the relations between the monetary and the fiscal authorities is the independence of the central bank from the government. In particular, the opportunity of direct monetary financing of budget deficits should normally be eliminated in a monetary union. The relations between the common central bank and the national governments of member countries of the monetary union should be specified accordingly in the relevant legislation. ${ }^{16}$ This should also include the distribution of central bank profits (seignorage) to governments (Box 3). Furthermore, freedom of the central bank from fiscal dominance implies that financial markets in countries of the monetary union have enough depth to absorb placements of public debt.

\footnotetext{
${ }^{14}$ The focus of this section is on a monetary union rather than a currency union. A currency union can also be "dollarization" which in principle does not require any coordinated efforts by member countries to have an adequate operating environment.

${ }^{15}$ Another important precondition for a currency union is the support of a substantial fraction of the population.

${ }^{16}$ The lack of control by the central bank over its refinancing of commercial and developmental banks can also lead to excessive indirect central bank lending to governments. This was seen as one of the factors that led to a crisis in the West African Monetary Union and Central African Monetary Union in the late 1980s and a devaluation in 1994 (Medhora, 2000).
} 


\section{Box 3. Distribution of Seignorage in a Currency Union}

Seignorage revenue can be viewed as a continued flow of returns accrued to the central banks because of its unique function of issuing money. The revenue is called "seignorage" because the central bank does not pay interest on the currency it issues while it collects interest on the assets obtained in exchange. Theoretically, seignorage revenue can be used by the central bank itself (to cover administrative expenses or adding to the reserves) or returned to the public. The transfer of seignorage revenue to the public can be achieved either via an explicit mechanism for transmitting central bank profits to the treasury, or using some less transparent quasifiscal activities. These quasi-fiscal activities could arise from the dual role of a central bank as regulator of the financial and foreign exchange systems and as the banker to the government.

In a currency union, the performance of the monetary policy function generates common seignorage revenue of the union. This seignorage normally accrues to the central bank of the union rather than to the central banks of the member countries. Therefore, member countries must decide how this revenue should be used (in case of "dollarization", the seignorage accrues to the central bank of a "dollarizing" country, and there is typically no sharing of seignorage with a "dollarized" country). In this regard, mainly concerned are the following three issues: (i) member countries' shares in the distribution of dividends of the central bank of the union;

(ii) treatment of quasi-fiscal activities of the central bank; and (iii) accountability of the central bank.

\section{Distribution of central bank dividends to member countries}

In a currency union, the common central bank and the member countries must agree on the countries' shares in the flow of distributed dividends. It can be argued that the main principle governing the distribution of central bank dividends should be avoidance of a bias against any member countries. In practice, existing currency unions (Central African Monetary Union, Eastern Caribbean Monetary Union, European Monetary Union, and West African Monetary Union) use different and sometimes complicated approaches for calculating the countries' shares (see table below).

\section{The treatment of quasi-fiscal activities of the central bank}

Quasi-fiscal activities of the central bank of a currency union can have a significant allocative impact. If quasifiscal activities can be quantified, they should be reflected in reduced transfers of dividends from the central bank of a currency union. While this would help reduce a bias against some member countries of a currency union, the discretionary effects of these activities would remain. More fundamental action (structural reform) is required in order to achieve a long-term solution.

\section{Accountability of the central bank}

In addition to setting up clear rules for the transfer of seignorage revenue to the public, central bank of a currency union should be made accountable to the public for the use of seignorage revenue by the bank itself. Periodic disclosure of information on operating expenses and revenues pertaining to central bank operations would help to dispel public doubts about the openness of the central bank with regard to the use of seignorage revenue. 


\section{Box 3. Distribution of Seignorage in a Currency Union (continued)}

Currency Union

\section{Central African Monetary} Union

(six member states: Cameroon, Central African Republic, Chad, Congo, Equatorial Guinea, and Gabon)

\section{Eastern Caribbean Currency Union} (eight member states: Anguilla, Antigua and Barbuda, Dominica, Grenada, Montserrat, St. Kitts and Nevis, St. Lucia, and St. Vincent and the Grenadines)

\section{European Monetary Union} (twelve member states: Austria, Belgium, Finland, France, Germany, Greece, Ireland, Italy, Luxembourg, the Netherlands, Portugal, and Spain)

\section{West African Monetary Union}

(eight member states: Benin, Burkina Faso, Côte d'Ivoire, Guinea-Bissau, Mali, Niger, Senegal, and Togo)

\section{Officially "Dollarized" Countries}

(Andorra, Ecuador, El Salvador, Kiribati, Liechtenstein, Monaco, Panama, San Marino)

\section{Formula for Distribution of Central Bank Profits}

The net central bank profits after provisions are distributed to member states according to the following formula:

- 15 percent of profits are distributed in proportion to the respective amounts of currency in circulation in each member state;

- 15 percent of profits are distributed in equal amounts to all member states; and

- 70 percent of profits are distributed based on the percentage of each member state's relative contribution to the central bank's outturn.

The share of distributable profits attributable to returns on investment of central bank's external assets is distributed between the member states in proportion to the respective amount of currency in circulation in each member state.

The share of distributable profits attributable to other revenue-earning activities of the central bank is distributed on the basis of the imputed equity interest of each member state in the central bank.

The sum of the national central banks' monetary income is allocated to the national central banks in proportion to their paid-up shares in the capital of the European Central Bank.

Under the transitional regime applicable until 2007, the amount of monetary income to be pooled is adjusted on the basis of compensating factors, which will be progressively reduced to zero.

After allocation to any optional reserve, be it general or special, the balance of central bank profits is allocated following a decision by the Council of Ministers of the Union.

Central bank profits are not allocated to "dollarized" countries.

Sources: the relevant Central Bank statutes; and ECB/2001/16 (the Decision of the ECB of December 6, 2001 on the allocation of monetary income of the national central banks of participating member states from the financial year 2002). 


\section{Financial sector soundness}

A strong and sound financial sector is another precondition for the long-term resilience of the monetary union. Financial instability can adversely affect the ability of the common central bank to exert monetary control. Furthermore, high cost of bailouts of financial institutions may produce substantial fiscal deficits in some member countries, which can weaken or even undermine the monetary union.

Sound functioning of the financial sectors, including those in monetary unions, requires an adequate regulation and supervision of financial institutions, and effective systemic liquidity support arrangements. These liquidity arrangements should in normal times prevent uncontrolled central bank liquidity support for financial institutions while establishing an adequate liquidity crisis management procedures. In particular, the central bank should have the option to provide systemically important financial institutions under stress with a lender of last resort (LOLR) support. Despite the possibility of increasing moral hazard, the existence of such a facility has long been recognized as an important element in managing a liquidity crisis. $^{17}$

\section{Setting Up an Asymmetric Currency Union}

Several specific issues should be taken into consideration in examining the asymmetric currency unions. In such unions, the assessment of costs and benefits of having a common currency should consider besides direct economic costs and benefits the following potentially important aspects. ${ }^{18}$

\section{Disadvantages of a small member country}

In an asymmetric currency union, the main disadvantage of a small member country arises from the fact that the conduct of monetary policy is essentially determined by the largest member country. When a small country decides to "dollarize" itself, it normally obtains no involvement in the monetary policy decision making. When the common monetary policy is conducted with inputs from all member countries, the influence of small countries is typically

\footnotetext{
${ }^{17}$ Eichengreen (2000) showed that hard pegs (including currency boards and officially dollarized economies) are more often associated with banking crises than soft pegs. He suggested that the reduction of moral hazard associated with the removal of some of the LOLR function may not be enough to offset the increase in bank difficulties originating in the lack of an LOLR facility.

${ }^{18}$ Dollarization or joining an existing monetary area on "unequal rights" are the main examples of asymmetric currency unions. In practice, however, almost all currency unions can be viewed as more or less asymmetric: even a common central bank managed jointly by all member countries may be more likely to conduct monetary policy that would primarily reflect the needs of the largest member country(ies).
} 
minor. ${ }^{19}$ Therefore, in the presence of asymmetric shocks small economies are most likely to bear brunt of costs that could arise from unfavorable exchange rate or interest rate movements, if there are no adequate mechanisms to deal with these shocks.

The costs for a small member country can increase when it agrees to lose (partly or completely) LOLR support and/or seignorage revenue. Regarding the LOLR facility, when a small country decides to "dollarize" or join an existing monetary area on unequal rights, an alternative arrangement for the LOLR facility needs to be found in order to safeguard the financial system. The central bank of a small country can, for example, accumulate foreign exchange reserves in sufficient amounts and keep a limited LOLR function. Another alternative is to negotiate a credit arrangement between a consortium of foreign banks and the central bank, under the terms of which the central bank can get sizable instant credit in the event of liquidity crisis. Besides, an efficient functioning of the interbank money market as well as the penetration of foreign banks (especially those from the large country of a currency union) can help prevent liquidity crisis and the need for a LOLR facility (see Broda and Levy Yeyati, 2003 for more details). ${ }^{20}$

Regarding the possible loss of seignorage revenue, several considerations need to be taken into account. A small country joining a currency union may obtain some representation in the common central bank and a share in the distribution of central bank profits (Box 3 ). If the small country joining a currency union does not obtain any representation in the common central bank, a special seignorage sharing arrangement can be negotiated. Such an arrangement can consist of either a constant flow of seignorage payments to the dollarized countries, calculated using a special formula, or a lump sum payment equal to the net present value of these flows (for more details, see Gruben, Wynne, and Zarazaga, 2003). A small country may decide to give up the seignorage if it believes that the benefits of the currency union are substantial enough to compensate for the loss of seignorage (see below).

\section{Benefits for a small member country}

The above discussed disadvantages of small countries in joining an asymmetric currency union can be outweighed by benefits from such a union. Such benefits include a reduction in borrowing costs through the lower exchange rate risk premium and an avoidance of costs of running a full-fledged central bank. Furthermore, small countries are typically more open to

\footnotetext{
${ }^{19}$ This can be illustrated by the arrangements within the European Monetary Union. In March 2003, the European Council decided to adapt the voting modalities in the ECB Governing Council to enlargement of EMU. As a result, national central bank governors who represent the biggest EU economies, will be able to exert their voting rights in about 80 percent of all ECB Governing Council meetings, while national central bank governors who represent the smallest EU economies, will only be able to vote in about 30 percent of ECB Governing Council meetings.

${ }^{20}$ In a situation when the LOLR facility is capped for all member countries according to their relative shares in GDP, some member countries can be disproportionately affected if the size of their banking systems is out of line with the GDP share.
} 
external trade than large countries, and therefore the benefits from savings on transaction costs are likely to be more important for small countries than for large countries.

The benefits associated with a reduction of the potentially high exchange rate risk premium can be substantial for small countries. Many small countries have a history of currency crises resulting from monetary mismanagement. Under these conditions, these countries are likely to substantially benefit from a currency union with a large country whose monetary policy has a good reputation and whose currency is substantially more stable. ${ }^{21}$ Such a union will reduce domestic currency risk for a smaller country, which will translate into the reduction of risk premium on interest rate thus stimulating investments and growth. Small countries also typically have less sophisticated and thin financial markets than large countries, which may contribute to high interest rate levels and/or high interest and exchange rate volatility. The more volatile and unpredictable is a country's exchange rate, the greater will be benefits from the elimination of domestic currency risk. ${ }^{22}$ This may also lead to a reduced need for foreign exchange reserves since small countries usually need more reserves than large countries to safeguard against excessive exchange rate volatilities.

Small countries may also opt for asymmetric currency unions to avoid the costs of running a full-fledged central bank. These costs primarily include administrative expenses, costs of managing foreign exchange reserves, and costs of printing and maintaining national currency.

\footnotetext{
${ }^{21}$ Alesina and Barro (2000) argue that a small country with a history of high inflation that is close to a large and monetarily stable country has the strongest incentive to give its own currency, while Berg and Borensztein (2002) argue that official dollarization may offer more benefits than costs in highly dollarized economies.

${ }^{22}$ It should be noted that while a currency union may reduce the exchange rate risk premium on interest rates, the country-specific risk premium will remain.
} 


\section{ECONOMIC COSTS AND BENEFITS OF CURRENCY UNIFICATION BETWEEN BELARUS AND RUSSIA}

This section assesses the suitability of economic conditions in Belarus and Russia to the formation of a successful currency union. In particular, the gains from having a common currency - in terms of reduced transaction costs in bilateral trade and an improved macroeconomic environment in Belarus - are reviewed against the costs arising from possible asymmetries of shocks affecting the two economies (Table 2 compares several macroeconomic and structural indicators of Belarus and Russia). The section also reviews to what extent mitigating factors would help reduce some of the possible costs.

\section{A. Trade Patterns}

Belarus was strongly integrated in the former USSR economy. More than a decade after the break up of the latter, the economy of Belarus remains closely connected to that of Russia. ${ }^{23}$ This is reflected in exports to Russia of around one third of GDP (more than half of total exports), and in purchases from Russia of 40 percent of GDP (around two-thirds of total imports; see Figures 1 and 2). Russia is by far the dominant trading partner of Belarus, since the second largest trading partner of Belarus (Germany) accounts for only around 10 percent of her imports and 5 percent of her exports. At the same time, Russia does less than 10 percent of her total external trade with Belarus. ${ }^{24}$

Against this assessment of trade patterns and taking into account the fact that more than half of trade between Russia and Belarus is carried out in Russian rubles, currency unification would give rise to some savings from reduction in transaction costs for Belarus, while being relatively insignificant for Russia. ${ }^{25}$ Even under assumption that the currency union will not substantially stimulate bilateral trade (because the existing volume of trade is already very high), currency unification will certainly bring savings, especially for Belarusian traders, from the elimination of transaction costs from currency conversion. The gains would be higher, of course, if trade between the two countries were to increase further.

\section{B. Macroeconomic Stability}

Since the early 1990s, the macroeconomic performance of Belarus has been one of the weakest among its neighbors. This has primarily resulted from the inability of the authorities

\footnotetext{
${ }^{23}$ To some extent, this may be related to the slowness in reforming of state owned enterprises in Belarus, which as a result continue to have difficulties in penetrating highly competitive Western markets.

${ }^{24}$ Nevertheless, Belarus is still one of the major trading partners of Russia (Figure 2).

${ }^{25}$ According to the NBB estimates, the Russian ruble and the Belarusian rubel are used in around 52 percent and 8 percent, accordingly, of trade transactions between Belarus and Russia. The remaining 40 percent of bilateral trade is done in other currencies, mainly the U.S. dollar.
} 
Table 2. Belarus and Russia: Basic Data, 2000-03

(in percent; otherwise indicated)

\begin{tabular}{|c|c|c|c|c|}
\hline & 2000 & 2001 & 2002 & 2003 \\
\hline \multicolumn{5}{|c|}{ GDP growth rates } \\
\hline Belarus & 5.8 & 4.7 & 5.0 & 6.8 \\
\hline Russia & 10.0 & 5.1 & 4.7 & 7.3 \\
\hline \multicolumn{5}{|l|}{ CPI (e.o.p.) } \\
\hline Belarus & 107.5 & 46.1 & 34.8 & 25.4 \\
\hline Russia & 20.1 & 18.6 & 15.1 & 12.0 \\
\hline \multicolumn{5}{|c|}{ Budget deficit (in percent of GDP) } \\
\hline Belarus & -0.2 & -1.9 & -1.8 & -1.4 \\
\hline Russia & 2.7 & 3.0 & 0.6 & 1.0 \\
\hline \multicolumn{5}{|c|}{ Central bank lending to the government as percent of GDP (net) } \\
\hline Belarus 1/ & 1.3 & 1.2 & -1.2 & 1.0 \\
\hline Russia & -1.2 & -1.9 & -0.6 & -1.4 \\
\hline \multicolumn{5}{|c|}{ Current account balance as percent of GDP } \\
\hline Belarus & -2.6 & -3.5 & -2.6 & -2.9 \\
\hline Russia & 17.8 & 10.7 & 8.8 & 8.9 \\
\hline \multicolumn{5}{|c|}{ Trade balance as percent of GDP } \\
\hline Belarus & -6.8 & -6.5 & -6.3 & -7.1 \\
\hline Russia & 23.1 & 15.7 & 13.2 & 13.9 \\
\hline \multicolumn{5}{|c|}{ Gross official reserves in months of imports } \\
\hline Belarus & 0.5 & 0.5 & 0.6 & 0.5 \\
\hline Russia & 5.5 & 5.7 & 6.9 & 9.1 \\
\hline \multicolumn{5}{|c|}{ Total external debt (as percent of GDP) } \\
\hline Belarus & 16.2 & 19.8 & 21.1 & 19.5 \\
\hline Russia & 62.1 & 49.1 & 43.4 & 39.2 \\
\hline \multicolumn{5}{|c|}{ Trade turnover (as percent of GDP) } \\
\hline Belarus & 120.2 & 141.3 & 130.8 & 136.2 \\
\hline Russia & 57.6 & 50.8 & 48.7 & 48.7 \\
\hline
\end{tabular}


Table 2. Belarus and Russia: Basic Data, 2000-03 (continued) (in percent; otherwise indicated)

\begin{tabular}{|c|c|c|c|c|}
\hline & 2000 & 2001 & 2002 & 2003 \\
\hline \multicolumn{5}{|l|}{ Population (in millions) } \\
\hline Belarus & 10.0 & 10.0 & 9.9 & n.a. \\
\hline Russia & 145.4 & 144.8 & 144.2 & n.a. \\
\hline \multicolumn{5}{|l|}{ GDP per capita (in US\$) } \\
\hline Belarus & 1,274 & 1,239 & 1,437 & n.a. \\
\hline Russia & 1,785 & 2,137 & 2,400 & n.a. \\
\hline \multicolumn{5}{|l|}{ Privatization of small enterprises (EBRD indicator 1/) } \\
\hline Belarus & 2 & 2 & 2 & 2.3 \\
\hline Russia & 4 & 4 & 4 & 4 \\
\hline \multicolumn{5}{|l|}{ Privatization of large enterprises (EBRD indicator 1/) } \\
\hline Belarus & 1 & 1 & 1 & 1 \\
\hline Russia & 3.3 & 3.3 & 3.3 & 3.3 \\
\hline \multicolumn{5}{|l|}{ Enterprise reform (EBRD indicator 1/) } \\
\hline Belarus & 1 & 1 & 1 & 1 \\
\hline Russia & 2 & 2.3 & 2.3 & 2.3 \\
\hline \multicolumn{5}{|l|}{ Banking system reform (EBRD indicator 1/) } \\
\hline Belarus & 1 & 1 & 1.7 & 1.7 \\
\hline Russia & 1.7 & 1.7 & 2 & 2 \\
\hline \multicolumn{5}{|l|}{ Nonbank financial institutions reform (EBRD indicator 1/) } \\
\hline Belarus & 2 & 2 & 2 & 2 \\
\hline Russia & 1.7 & 1.7 & 2.3 & 2.7 \\
\hline Belarusian GDP as percent of Russian GDP & 4.9 & 4.1 & 4.2 & 4.0 \\
\hline Belarusian reserve money as percent of Russian reserve money & 1.9 & 2.3 & 2.0 & 1.6 \\
\hline Belarusian (rubel) M2 as percent of Russian (ruble) M2 & 1.3 & 1.5 & 1.6 & 1.4 \\
\hline
\end{tabular}

Sources: Belarus and Russia authorities, EBRD, and authors' estimates.

1/ The EBRD indicators of small-scale and large-scale privatization, enterprise reform, banking system reform, and nonbank financial institutions reform have a range between 1 and 4+, where higher figure corresponds to more advanced stage reached in privatization/reforms. 
Figure 1. Belarus: External Trade Partners (in percent of total; as of 2002)

A. Exports

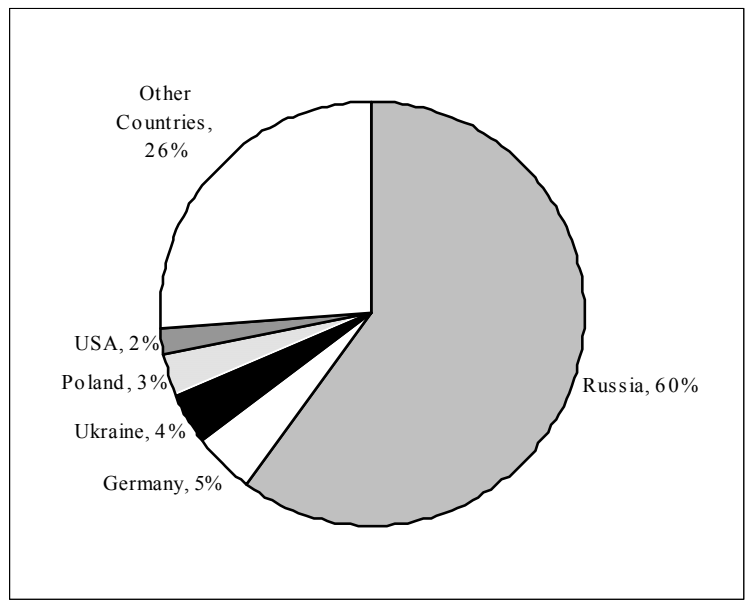

B. Imports

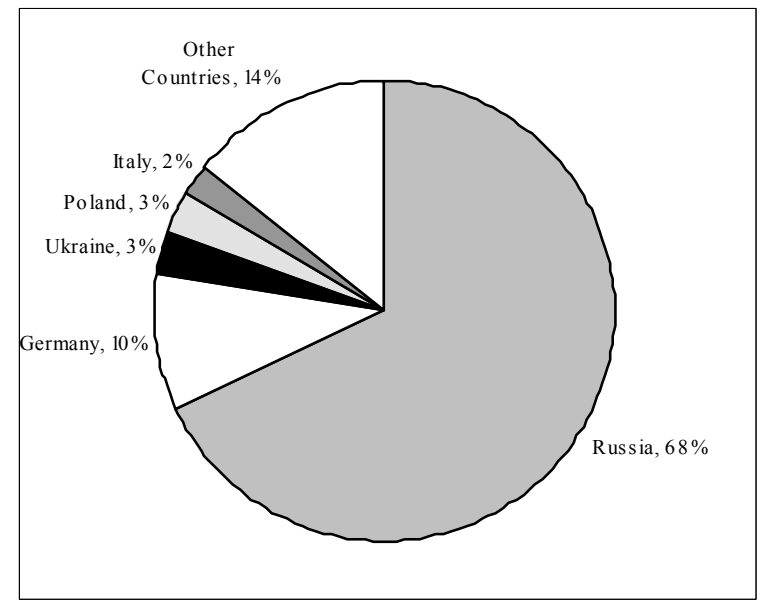

Source: IMF, Direction of Trade Statistics, 2003.

Figure 2. Russia: External Trade Partners (in percent of total; as of 2002)

A. Exports

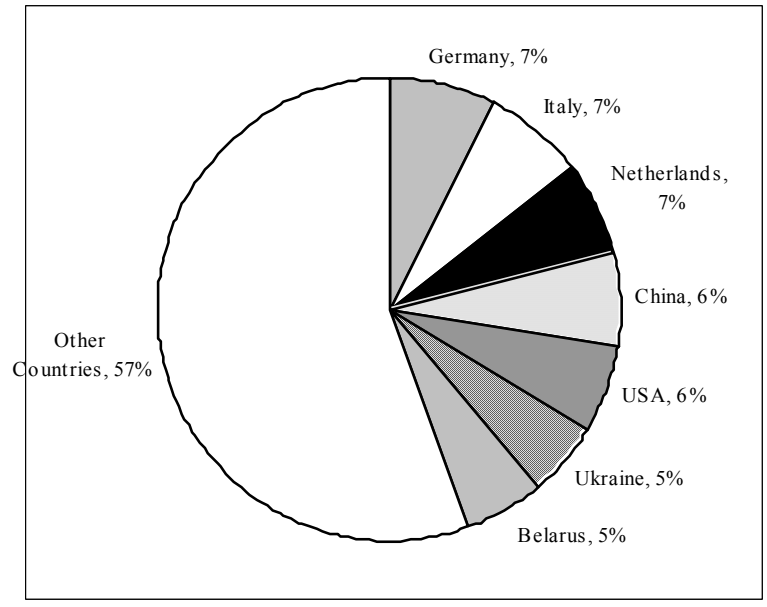

B. Imports

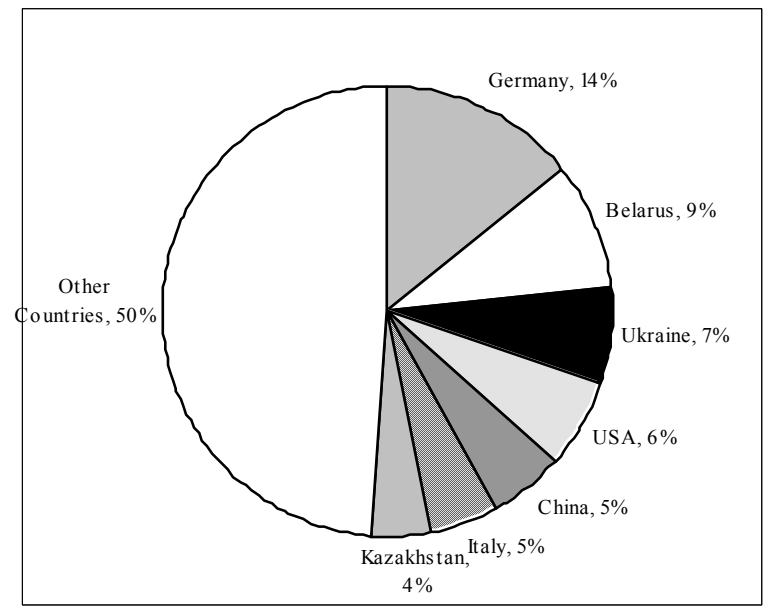

Source: IMF, Direction of Trade Statistics, 2003. 
to implement a prudent fiscal policy and the reliance on inflationary (central bank) financing of budget deficits (Table 2). Despite the declining trend, the inflation rate in Belarus has been the highest among the CIS countries in the last five years. High inflation and depreciation of the currency, in turn, have contributed to dollarization of the economy and inability to attract sizable foreign investments.

Therefore, a major benefit of a currency union with Russia for Belarus could be a relatively more stable macroeconomic environment. In fact, the currency union would allow Belarus to “import” Russia's current macroeconomic stability. The union would likely contribute to a reduction in the inflation rate and the exchange rate risk in Belarus. Lower inflation would reduce distortions in the economy and uncertainty for investors, thus bringing down real interest rates. As to the exchange rate risk, a currency union would completely eliminate the $\mathrm{RBL} / \mathrm{RUB}$ exchange rate risk, though the exchange rate risk with other currencies would remain. ${ }^{26}$ The resulting improvement in macroeconomic performance would foster new investments and contribute to a closer integration of Belarus with Russia and the rest of the world.

The sustainability of macroeconomic stability in Belarus would, however, require the successful implementation of fiscal adjustment and structural reforms (Section V). In particular, the fiscal policy should be adjusted in order not to create a background of uncertainty, which can result in a significant interest rate premium and weak demand for government securities. Similarly, the health of the banking system needs to be credible in the eyes of public.

\section{Asymmetry of Shocks}

Regional shocks, especially the shocks to the terms of trade, are likely to have a highly asymmetric impact on Belarus and Russia, mainly due to the different production structures and degrees of openness of the two countries (Table 2, Figures 3 and 4). ${ }^{27}$ Belarus has large foreign trade and agricultural sectors, while Russia has large energy and non-tradable goods sectors. Belarus exports mainly processed goods, while raw materials dominate Russia's exports. Accordingly, business cycles in the two countries are prone to different patterns, leading to rather weak estimates of the correlation between Russian and Belarusian GDP growth. ${ }^{28}$

\footnotetext{
${ }^{26}$ At the time of writing, Belarus maintains a crawling band foreign exchange regime against both the U.S. dollar and Russian ruble. Such targeting both the U.S. dollar and the Russian ruble since end-2002 has been de facto consistent because the RUB/USD exchange rate has been relatively stable.

${ }^{27}$ It is interesting to note that the shocks are also likely to have a highly asymmetric impact on different regions of Russia itself.

${ }^{28}$ Using quarterly data for the period 1997-2002, and adjusting for seasonality, the correlation coefficient between real GDP growth rates in Belarus and Russia is estimated at only 0.14 .
} 
Figure 3. Belarus: GDP and Employment by Sectors (in percent of total; as of 2002)

A. GDP

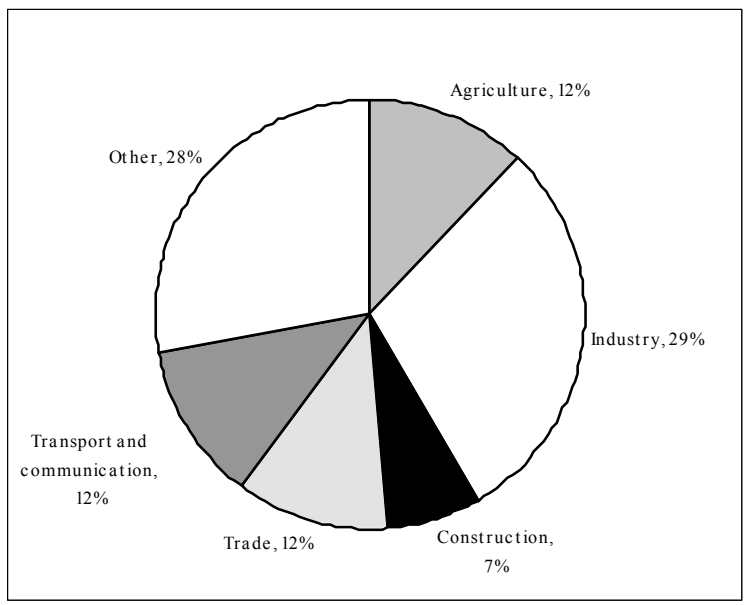

B. Employment

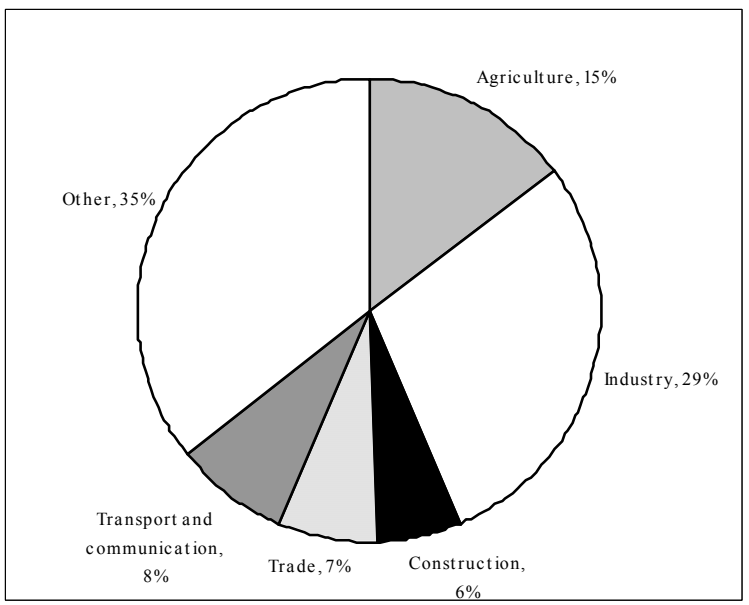

Source: IMF Statistical Appendices to the Country Reports.

Figure 4. Russia: GDP and Employment by Sectors (in percent of total; as of 2002)

A. GDP

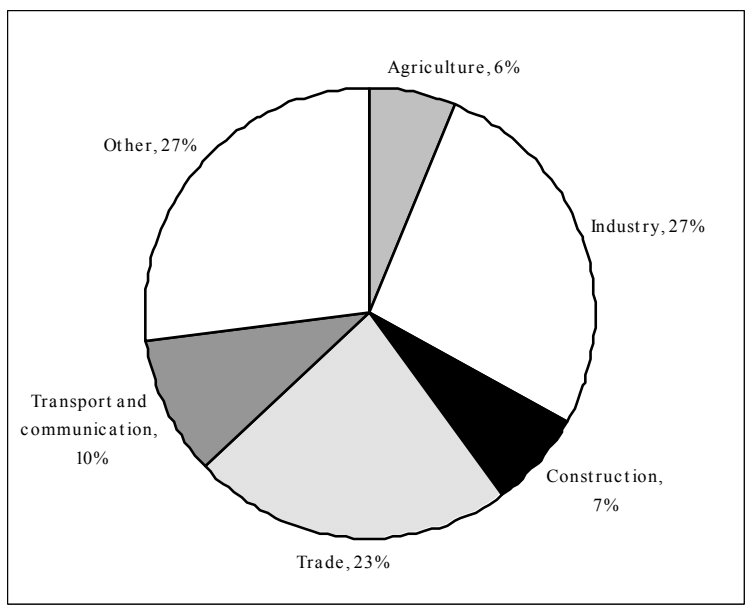

B. Employment

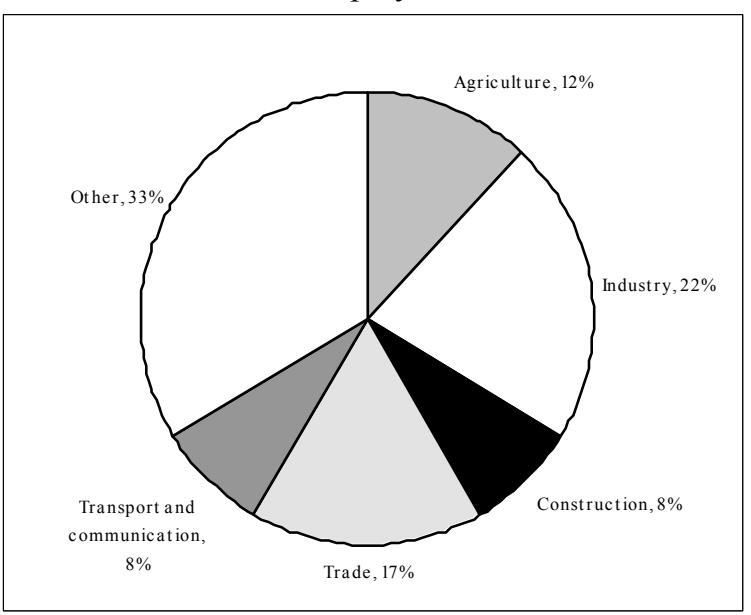

Source: IMF Statistical Appendices to the Country Reports. 
On this basis, a common currency with Russia is likely to make the economy of Belarus more vulnerable to external shocks. For example, a continued strengthening of the common currency due to a favorable external environment for Russia (e.g., in the case of persistently high world prices for oil and other major Russian exports) could potentially undermine competitiveness and growth in Belarus. ${ }^{29}$

\section{Are There Mechanisms to Deal with the Asymmetries?}

One important factor that could mitigate some of the differences between the structures of the Belarusian and Russian economies is the character of bilateral trade between them. Belarusian-Russian trade rests to a large extent on processing of raw materials and energy into chemicals, refined oil products, and other finished manufactures-largely for export to third countries. For example, significant oil processing factories in Belarus-built essentially during the Soviet era-remain linked to Russian oil production. Therefore, a shock affecting the tradable goods sector of Russia may well affect the tradable goods sector of Belarus in a symmetric way.

Other more orthodox mechanisms to deal with the asymmetric responses to macroeconomic shocks may include: (i) labor mobility; (ii) wage flexibility; and (iii) fiscal transfers.

\section{Labor mobility}

Labor mobility between Belarus and Russia could potentially be very high. Belarus and Russia were part of one country for a very long time, and the Belarusian and Russian population continue to have strong ties. Common marriages are widespread, reflecting the common culture and the very great similarity of the languages. The geographical proximity and the absence of visa requirements could also facilitate labor mobility.

There are no reliable data on labor mobility between Belarus and Russia, but at present it is likely to be low. Internal mobility of labor is low within Russia itself (Andrienko and Guriev, 2003), which may to some extent reflect the existing administrative barriers. ${ }^{30}$ High relocation costs and the relatively underdeveloped housing market are also important factors limiting labor mobility, as they financially constrain the people who would like to migrate. ${ }^{31}$

\footnotetext{
${ }^{29}$ High productivity growth in Russia, resulting for example from vigorous enterprise restructuring or new investments may cause a similar result.

${ }^{30}$ Ekman (2000), for example, claims that that the Soviet system of resident permits, propiska, has survived in Russia, even though this violates Russia's constitution.

${ }^{31}$ Andrienko and Guriev (2003) claim that up to one third of Russian regions are locked in poverty trap, where people do not have adequate resources to move to the prospering regions.
} 
High non-wage benefit spending and residual state provision of "social services" in Belarus may also have discouraged people from moving out of Belarus (Sewell, 1997). ${ }^{32}$

\section{Wage flexibility}

While there has been significant progress in liberalizing wages in Russia, wages in Belarus remain tightly controlled by the state. ${ }^{33}$ By preventing real wages from adjusting to equate desired labor supply with enterprises' demand for labor, limited wage flexibility in Belarus has contributed to a weak financial situation of enterprises and an increase in fiscal imbalances.

\section{Fiscal transfers}

Fiscal transfers could be an effective mechanism to deal with the asymmetries noted above. In this regard, it can be argued that the effects of external shocks on Belarus should not differ substantially from those on the neighboring Briansk, Pskov, or Smolensk provinces of Russia, which have production structures that are broadly similar to Belarus (in particular, large agricultural sectors and almost no mineral resources). These provinces, however, may receive fiscal transfers from the federal government of Russia, which would help them absorb shocks.

However, there has been no agreement on creation of a similar fiscal federalism arrangement between Belarus and Russia to support the currency unification. Although Belarus has requested compensation from Russia in connection with losses due to continued use of the origin principle for assessing indirect tax liability in bilateral trade, there are no plans to create an explicit interstate fiscal transfer mechanism (like the "Cohesion Fund" in the European Union, which is designed to subsidize poorer regions). ${ }^{34}$

\footnotetext{
${ }^{32}$ Following the Soviet tradition, Belarusian enterprises provide financing for housing for employees, kindergartens and summer camps for employee's children, as well as maintaining local infrastructure such as heating, electricity, water, etc. In contrast, state-owned enterprises in Russia have been largely freed from such obligations.

${ }^{33}$ The Belarusian government carries out this control in the public sector through the tarifnaya setka (tariff system), based on tariff scales, the tariff rate of the first grade, and tariff qualification guide. Under this system, the government sets up the tariff rate of the first grade, which automatically affects other grades. This system tends to compress wage differences, even though bonuses and other payments that employees receive weaken this tendency (for details, see IMF, 2004b). The Russian government uses a similar system, but the share of the public sector in Russia is almost half as low as in Belarus. Another illustration of the wage control in Belarus is the instruction from the President of Belarus to increase monthly wages in Belarus to at least an equivalent of US $\$ 250$ by end-2005 from below US\$100 in 2001.

${ }^{34}$ Since mid-2000, Russia moved to the origin principle of levying VAT. The estimates of "losses" to the budget of Belarus caused by compensation of the VAT that Belarusian companies pay to the Russian budget ranges between US $\$ 150$ million and US\$200 million per year. The Russian authorities reportedly promised to reimburse Belarus for such losses starting from the time of establishing a currency union and for two years prior to the establishment of the currency union.
} 
Until 2004, Belarus received large implicit import subsidies from Russia in the form of low prices for natural gas. ${ }^{35}$ These subsidies allowed Belarusian households and enterprises to pay lower electricity and heating prices than would otherwise be possible. As such, they represented a sort of mechanism that helped to cushion asymmetric shock hitting gas producing and gas consuming regions. Since early-2004, however, Belarus had to import gas at much higher prices from other Russian suppliers as Gazprom stopped supplying Belarus with gas after the Belarusian authorities and Gazprom failed to reach an agreement on privatization of Beltransgaz (see IMF, 2004a). In June, 2004, Belarus and Russia agreed that Russia would sell gas to Belarus at the price that now applies to Ukraine while Belarus would charge higher tariffs for gas transit through its territory by Gazprom.

\section{IS OPERATIONAL ENVIRONMENT SUPPORTIVE OF A CURRENCY UNIFICATION OF BELARUS AND RUSSIA?}

\section{A. Fiscal and Quasi-Fiscal Management}

In recent years, the fiscal position of Belarus has been significantly worse than that of Russia. During 2000-03, Belarus posted a budget deficit averaging 1.3 percent of GDP, compared with an average budget surplus of 1.8 percent of GDP in Russia (Table 2). Although the current level of the budget deficit in Belarus is not high, and the external debt of Belarus remains relatively small (partly because the foreign creditors have shied away from lending to Belarus), tighter fiscal policy is still needed in Belarus, for the following reasons:

- $\quad$ First, the reported budget deficit data do not fully reflect the stance of fiscal policy in Belarus. This is because of the widespread use of quasi-fiscal activities, including energy cross-subsidies and directed credits from the state-owned commercial banks to specific classes of borrowers, often at below market rates.

- $\quad$ Second, at least until 2004, a large share of the budget deficit in Belarus had been financed by direct lending from the NBB (Table 2). In contrast, the CBR has been prohibited from direct lending to the government in Russia since $1995 .{ }^{36}$ Under the monetary union agreement, however, the Belarusian government's access to the central bank resources would either be prohibited or significantly limited.

\footnotetext{
${ }^{35}$ Under an agreement signed at the time the JAP was agreed, Belarus was to receive a quota according to which the Russian natural gas monopoly Gazprom would deliver gas at the same low price as that in border regions in Russia (this price is typically only about a third of the world market price), conditioned on the sale of a significant stake in the gas transport and distribution firm Beltransgaz.

${ }^{36}$ An easy access of the Belarusian government to the central bank resources had hindered the development of an active treasury bill and bond markets. An administratively imposed interest rate ceiling on government securities (equal to the refinance rate) and weak portfolio management in financial institutions have also contributed to this outcome.
} 
- $\quad$ Third, fiscal adjustment is needed owing to limited access by Belarus to international capital markets. During 2000-03, for example, net foreign financing of the consolidated budget deficit amounted to minus 0.1 percent of GDP, which means that Belarus was repaying foreign creditors despite financing needs. The currency union may, however, increase the Belarusian government's access to the financing from Russia's capital markets.

- $\quad$ Finally, without necessary structural reforms (see below), Belarusian output growth is likely to stagnate or decline in the long term. This may increase the burden on fiscal management in the future.

The fiscal adjustment mostly needs to come from streamlining expenditures as Belarusian enterprises have a higher tax burden compared with their counterparts in Russia (the ratio of tax revenues to GDP in Belarus is one of the highest among transition countries). The state dominance of the economy largely contributed to this outcome in the past. But the experiences of the other CIS countries show that structural reforms may increase tax avoidance and reduce tax revenues.

\section{B. Financial Sector Policies}

In general, the financial sectors in both countries remain relatively underdeveloped and dominated by the state-owned commercial banks. However, privatization and corporate sector reforms in Russia have allowed it to develop a relatively more advanced banking system as well as a vigorous stock market (Table 2). All available indicators show that the level of financial intermediation in Belarus is considerably shallower than that in Russia (Table 3). Compared to Belarus, Russia has higher ratios of monetization and credit to economy (in terms of GDP), and a higher money multiplier. The largest Russian banks are also substantially bigger than the largest Belarusian banks in terms of capital or assets. ${ }^{37}$ In 2003, the capitalization of the Russian stock market amounted to an equivalent of 37 percent of GDP, compared with insignificant amounts in Belarus. ${ }^{38}$

\footnotetext{
${ }^{37}$ Using the data as of end-2003, the largest two Belarusian banks can be ranked among respectively the second and fourth dozen of the largest Russian banks in terms of assets.

${ }^{38}$ The Belarusian Currency and Stock Exchange reports only about US\$0.5 million turnover in stock trading in 2001.
} 
Table 3. Belarus and Russia: Selected Financial Intermediation Indicators, 2000-03

\begin{tabular}{|c|c|c|c|c|}
\hline & 2000 & 2001 & 2002 & 2003 \\
\hline \multicolumn{5}{|c|}{ Domestic currency broad money (in percent of GDP) } \\
\hline Belarus & 7.0 & 7.3 & 7.6 & 9.5 \\
\hline Russia & 15.7 & 17.9 & 19.6 & 24.2 \\
\hline \multicolumn{5}{|c|}{ Total broad money (in percent of GDP) } \\
\hline Belarus & 17.4 & 15.2 & 15.0 & 17.1 \\
\hline Russia & 21.4 & 23.7 & 26.2 & 29.8 \\
\hline \multicolumn{5}{|c|}{ Credit to the economy (in percent of GDP) } \\
\hline Belarus & 16.5 & 14.9 & 15.4 & 17.8 \\
\hline Russia & 13.1 & 16.7 & 18.7 & 22.4 \\
\hline \multicolumn{5}{|c|}{ Domestic currency broad money multiplier } \\
\hline Belarus & 2.01 & 1.84 & 2.09 & 2.07 \\
\hline Russia & 2.20 & 2.23 & 2.27 & 3.27 \\
\hline \multicolumn{5}{|c|}{ Spread between 3-month deposit and lending rates (in percent) } \\
\hline Belarus & 0.5 & 16.5 & 10.5 & 11.5 \\
\hline Russia & 6.6 & 9.2 & 6.5 & 7.5 \\
\hline \multicolumn{5}{|c|}{ Dollarization ratio (FX deposits in percent of total broad money) } \\
\hline Belarus & 59.8 & 52.1 & 49.2 & 44.4 \\
\hline Russia & 26.9 & 24.5 & 25.4 & 18.9 \\
\hline \multicolumn{5}{|c|}{ Number of commercial banks } \\
\hline Belarus & 31 & 29 & 28 & n.a. \\
\hline Russia & 1,311 & 1,319 & 1,329 & n.a. \\
\hline \multicolumn{5}{|c|}{ Stock market capitalization (in percent of GDP) } \\
\hline Belarus & 4.1 & 2.9 & n.a. & n.a. \\
\hline Russia & 15.3 & 25.7 & 36.5 & n.a. \\
\hline
\end{tabular}

Sources: Belarus and Russia authorities, EBRD; and authors' estimates. 
Reported financial soundness indicators are generally more favorable in Russia than in Belarus (Table 4). ${ }^{39}$ While the Belarusian banks report relatively high levels of capital and declining levels of non-performing loans, official data indicate that almost half of the enterprise sector is loss-making, which raises questions about the adequacy of accounting loan classification standards. In addition, there is a substantial exposure of Belarusian banks to the direct and indirect foreign exchange risks, given the high proportion of foreign exchange assets and liabilities - predominantly US\$-denominated — on bank balance sheets. These foreign exchange risks are compounded by the very low level of international reserves at the NBB (Table 2).

Poor performance of the Belarusian banks is largely a result of state interventions in the operational management of banks. The Belarusian government owns directly or indirectly the four largest banks in the country which have a market share of around 70 percent in terms of assets. The state uses these banks to make loans to "priority" sectors or enterprises, sometimes at preferential terms. In turn, these banks are treated favorably in access to central bank and government resources. The state dominance of the banking system and the absence of a market environment have hindered incentives for banks to improve their credit assessment and risk management capacities, and these state-controlled Belarusian banks are periodically recapitalized by the Belarusian government. This situation will need to be addressed before the establishment of a currency union, because the possibility to recapitalize Belarusian banks or even to provide LOLR support will be substantially reduced or completely eliminated.

\section{Business Environment}

In contrast to Russia, the business environment in Belarus is characterized by government control of around 80 percent of the economy. The Belarusian government assigns production targets for companies that it controls, does not allow them to lay off redundant labor, sets administrative wage targets, and forces enterprises to carry out quasi-fiscal activities, including cross-subsidizing other enterprises. Although these enterprises get support from the government by receiving directed credits and tariff and non-tariff protection, about half of them are loss making, and without changes in the institutional and regulatory environment, the proportion of these loss making companies may grow further.

The nascent Belarusian private sector, on the other hand, is suffering from "red tape," including cumbersome licensing requirements, interventions of tax officials, and continuing changes in regulations. The state continues to maintain the right to introduce a "golden share" in a private company, even if doing so was not foreseen at the time the companies were privatized (the President of Belarus may issue a decree giving the government effective

\footnotetext{
${ }^{39}$ Russian banks also have better ratings of international rating agencies than their Belarusian counterparts. For example, in 2003, Fitch rated many Russian banks "B" while at the same time it rated only one bank in Belarus with the rating "C."
} 
control in any enterprise in which the state retains even one share). As a result, Belarus has not been able to attract sizeable FDI. ${ }^{40}$

Table 4. Belarus and Russia: Selected Financial Soundness Indicators, 2000-03

\begin{tabular}{lrrrr}
\hline & 2000 & 2001 & 2002 & 2003 \\
& & & & \\
& & & & \\
& & & & \\
Capital adequacy ratio & 24.4 & 20.7 & 24.2 & 27.3 \\
$\quad$ Belarus & 19.0 & 20.3 & 19.1 & 19.1 \\
$\quad$ Russia & & & & \\
Nonperforming loans (in percent of total loans) & 15.2 & 14.4 & 8.3 & 3.7 \\
$\quad$ Belarus & 7.7 & 6.2 & 5.6 & 5.0 \\
$\quad$ Russia & & & & \\
Loan loss provisions (in percent of nonperforming loans) & & & & \\
$\quad$ Belarus & 77.6 & 57.5 & 28.8 & 51.7 \\
$\quad$ Russia & 102.6 & 108.1 & 112.5 & 118.0 \\
& & & & \\
Return on assets & & & & \\
$\quad$ Belarus & 1.0 & 0.8 & 1.0 & 1.2 \\
$\quad$ Russia & 0.9 & 2.4 & 2.6 & 2.6 \\
& & & & \\
Return on equity & & & & \\
$\quad$ Belarus & & & & \\
$\quad$ Russia & 4.8 & 4.9 & 4.4 & 6.1 \\
& 8.0 & 19.4 & 18.0 & 17.8 \\
\hline
\end{tabular}

Sources: Belarus and Russia authorities, and authors' estimates.

The government's unwillingness to let state enterprises gain operational independence has undermined the privatization process. The high quasi-fiscal burden attached to the privatization terms, for example, led to the failure of the Belarusian government's efforts to divest parts of its shares in large petrochemical companies in 2002.

The currency union is expected to strengthen competition and limit quasi-fiscal support to public enterprises. Therefore, the Belarusian authorities need to take measures to increase viability of enterprises by leveling the playing field with Russia, including by harmonizing its tax and commercial laws, business codes and regulation with those of Russia. Privatization of state-owned enterprises by allowing enterprises to have operational independence and to

\footnotetext{
${ }^{40}$ A large portion of current FDI to Belarus comes from a single project, Gazprom's Yamal-Europe pipeline.
} 
abandon loss making activities would largely facilitate achieving these goals as well as attract foreign investments.

\section{Conclusion}

The long-run net economic effects of a proposed currency union between Belarus and Russia is not clear. On the one hand, strong trade integration between the two economies and the relatively weak macroeconomic performance of Belarus suggest that the currency union would bring substantial benefits for Belarus from reduced transaction costs and an improved macroeconomic environment. On the other hand, the macroeconomic symmetry condition is not satisfied: Belarus and Russia have different economic structures and therefore are subject to asymmetric shocks. Indeed, the correlation between real GDP growth in the two countries has been relatively small. The special character of trade between the two countries as well as the potential for growth in factor mobility may, however, at least partly offset the costs of asymmetric shocks.

A further critical challenge for a successful currency union of Belarus and Russia lies with the establishment of an adequate operating environment. Belarus needs to accelerate its institutional and structural reforms to catch up with Russia. These reforms should include a comprehensive fiscal adjustment aimed at the reduction of the budget deficit and the elimination of quasi-fiscal operations and heavy state control over the economy. The setting up of a currency union between Belarus and Russia may act as a catalyst to advance structural reforms in Belarus, but unless undertaken swiftly and in advance of the monetary unification, the currency union would be akin to "shock therapy" with immediate full curtailment of fiscal subsidies and quasi-fiscal support for enterprises and banks in Belarus.

Finally, the currency union can only work if there is a centralized monetary policy and a strong central bank which can conduct this policy. The history of the monetary disintegration of Belarus and Russia in 1993 can be illustrative in this regard. Incentives for excessive monetary expansion by the central banks of Belarus, Russia, and all other countries that formed the Soviet Union, and lack of a centralized monetary policy due to the breakdown of the central planning led to uncontrolled inflation in 1991-93, contributing to the dissolution of the "ruble zone." Therefore, the currently debated currency union between Belarus and Russia can work only if either (i) Belarus "ruble-izes" its economy by accepting to use the Russian ruble on the terms and conditions of the CBR, or (ii) both countries agree on a greater extent of economic and political integration - along with monetary unification - with the attendant willingness of Russia to engage in large scale fiscal transfers to facilitate the restructuring of the Belarusian economy. Anything in the middle is bound to fail. 


\section{REFERENCES}

Alesina, Alberto, and Robert J. Barro, 2000, “Currency Unions,” NBER Working Paper No. 7927 (Cambridge, Massachusetts: National Bureau of Economic Research).

Andrienko, Yuri, and Sergei Guriev, 2003, "Determinants of Interregional Mobility in Russia" Evidence from Panel Data," Center for Economic and Financial Research. Available via the Internet: http://www.cefir.org/Papers/cefwp25.pdf.

Bayoumi, T., and B. Eichengreen, 1992, "Is There a Conflict Between EC Enlargement and European Monetary Unification?” NBER Working Paper No. 3950 (Cambridge, Massachusetts: National Bureau of Economic Research).

Berg, Andrew, and Eduard Borensztein, 2000, "The Pros and Cons of Full Dollarization," IMF Working Paper 00/50 (Washington, DC: International Monetary Fund).

Boone, Laurence, and Mathilde Maurel, 1999, "An Optimal Currency Area Perspective of the EU Enlargement to the CEECs," CEPR Discussion Paper No. 2119 (London: Centre for Economic Policy Research).

Broda, Christian, and Eduardo Levy Yeyati, 2003, "Dollarization and the Lender of Last Resort," in Dollarization, ed. by Eduardo Levy Yeyati and Frederico Sturzenegger (Cambridge: Massachusetts: MIT Press).

Colton, Timothy J., 2002, "Belarusian Public Opinion and the Union with Russia" in Independent Belarus: Domestic determinants, Regional Dynamics, and Implications for the West, ed. by Margarita M. Balmaceda, James I. Clem, and Lisbeth L. Tarlow (Cambridge: Massachusetts: Harvard University Press).

Eichengreen, Barry, 2000, "When to Dollarize," paper presented at the conference "Dollarization: A Common Currency for the Americas?" organized by the Federal Reserve Bank of Dallas, March 6 and 7, 2000. Available via the Internet: http://www.dallasfed.org/news/latin/00dollar eichengr.pdf.

Ekman, Peter, 2000, “Two Kopek's Worth - Passports Are the Root of All Evil,” The Moscow Times, November 3.

Emerson, Michael, and others, 1992, One Market One Money (Oxford: Oxford University Press).

Fischer, Stanley, 2001, “Exchange Rate Regimes: Is the Bipolar View Correct?” paper presented at the Meetings of the American Economic Association, New Orleans, January 6, 2001. Available via the Internet http://www.imf.org/external/np/speeches/2001/010601a.htm. 
Frankel, Jeffrey A., 1999, "No Single Currency Regime Is Right for All Countries or at All Times," NBER Working Paper No. 7338 (Cambridge, Massachusetts: National Bureau of Economic Research).

, and Andrew K. Rose, 1996, "The Endogeneity of the Optimum Currency Area Criteria,” NBER Working Paper No. 5700 (Cambridge, Massachusetts: National Bureau of Economic Research).

,2000, "Estimating the Effect of Currency Unions on Trade and Output," NBER Working Paper No. 7857 (Cambridge, Massachusetts: National Bureau of Economic Research).

Ghosh, Atish R., Anne-Marie Gulde, and Holger C. Wolf, 2003, Exchange Rate Regimes: Choices and Consequences (Cambridge, Massachusetts: MIT Press).

Gruben, William C., Mark A. Wynne, and Carlos E. J. M. Zarazaga, 2003, "Implementation Guidelines for Dollarization and Monetary Unions," in Dollarization, ed. by Eduardo Levy Yeyati and Frederico Sturzenegger (Cambridge, Massachusetts: MIT Press).

International Monetary Fund, 2004a, "Republic of Belarus - Staff Report for the 2004 Article IV Consultation,“ IMF Country Report No. 04/141 (Washington, DC: International Monetary Fund).

, 2004b, "Republic of Belarus_-Selected Issues," IMF Country Report No. 04/139 (Washington, DC: International Monetary Fund).

Krugman, Paul, 1993, "Lessons of Massachusetts for EMU," in F. Giavazzi and F. Torres, eds. The Transition to Economic and Monetary Union in Europe (New York: Cambridge University Press), pp. 241-61.

Medhora, Rohinton, 2000, "Dollarization in the Americas: Lessons From the Franc Zone?" paper prepared for the NSI conference on Dollarization in the Western Hemisphere, Ottawa, October 4 and 5, 2000.

Mundell, Robert A., 1961, “A Theory of Optimum Currency Areas,” The American Economic Review, Vol. 51, Issue 4 (September).

Odling-Smee, John, and Gonzalo Pastor, 2001, “The IMF and the Ruble Area, 1991-93," IMF Working Paper 01/101 (Washington, DC: International Monetary Fund).

Sala-i-Martin, Xavier, and Jeffrey Sachs, 1991, "Fiscal Federalism and Optimum Currency Areas: Evidence for Europe from the United States," NBER Working Paper No. 3855 (Cambridge, Massachusetts: National Bureau of Economic Research). 
Sewell, David, 1997, "Enterprises Divesting Social Assets - The Belarus Story,” World Bank Transition Newsletter, Vol. 8, No. 3. Available via the Internet http://www.worldbank.org/html/prddr/trans/mayjun97/art5.htm. 